\title{
Age structure and disturbance legacy of North American forests
}

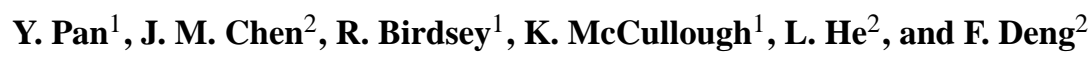 \\ ${ }^{1}$ US Forest Service Northern Global Change Program, Newtown Square, PA 19073, USA \\ ${ }^{2}$ Department of Geography University of Toronto, Ontario, M5S 3G3, Canada
}

Received: 17 December 2009 - Published in Biogeosciences Discuss.: 10 February 2010

Revised: 15 February 2011 - Accepted: 16 February 2011 - Published: 18 March 2011

\begin{abstract}
Most forests of the world are recovering from a past disturbance. It is well known that forest disturbances profoundly affect carbon stocks and fluxes in forest ecosystems, yet it has been a great challenge to assess disturbance impacts in estimates of forest carbon budgets. Net sequestration or loss of $\mathrm{CO}_{2}$ by forests after disturbance follows a predictable pattern with forest recovery. Forest age, which is related to time since disturbance, is a useful surrogate variable for analyses of the impact of disturbance on forest carbon. In this study, we compiled the first continental forest age map of North America by combining forest inventory data, historical fire data, optical satellite data and the dataset from NASA's Landsat Ecosystem Disturbance Adaptive Processing System (LEDAPS) project. A companion map of the standard deviations for age estimates was developed for quantifying uncertainty. We discuss the significance of the disturbance legacy from the past, as represented by current forest age structure in different regions of the US and Canada, by analyzing the causes of disturbances from land management and nature over centuries and at various scales. We also show how such information can be used with inventory data for analyzing carbon management opportunities. By combining geographic information about forest age with estimated $\mathrm{C}$ dynamics by forest type, it is possible to conduct a simple but powerful analysis of the net $\mathrm{CO}_{2}$ uptake by forests, and the potential for increasing (or decreasing) this rate as a result of direct human intervention in the disturbance/age status. Finally, we describe how the forest age data can be used in large-scale carbon modeling, both for land-based biogeochemistry models and atmosphere-based inversion models, in order to improve the spatial accuracy of carbon cycle simulations.
\end{abstract}

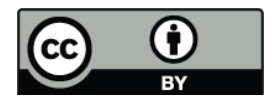

Correspondence to: Y. Pan (ypan@fs.fed.us)

\section{Introduction}

Most forests of the world are recovering from a past disturbance. According to a recent global forest resources assessment, $36 \%$ of the world's 4 billion ha of forest are classified as primary forest, i.e., showing no significant human impact (FAO, 2005). The same report estimates that 104 million $\mathrm{ha} \mathrm{yr}^{-1}$ of the world's forests, or $3 \%$ of the total area, are disturbed each year by fire, pests, and weather, though this is a significant underestimate of the disturbance rate because of incomplete reporting by countries. For the US, it is estimated that about half of the forest area, or 152 million ha, is disturbed each decade, but this estimate covers a wide range of disturbance types including timber harvesting and grazing which affect more area than natural disturbances (Birdsey and Lewis, 2003). In Canada, wildfires were the largest disturbance type in the 20th century, affecting an average of 2.6 million ha per year in the last two decades (Stocks et al., 2002; Weber and Flannigan, 1997). Insect pests are also significant and likely to increase in the future according to model simulations (Kurz et al., 2008a).

The net sequestration or loss of $\mathrm{CO}_{2}$ by forests after disturbance follows a predictable pattern determined by age, site, climate, and other factors (Pregitzer and Euskirchen, 2004). Typically, regenerating forests grow at an accelerating rate that reaches a peak at about the time the canopy closes, followed by a declining rate of increase that may last for centuries. A recent review of data from old-growth forests concluded that they may continue to sequester atmospheric $\mathrm{CO}_{2}$ indefinitely (Luyssaert et al., 2008), with continued increases in soil C as a likely long-term repository (Zhou et al., 2006). Disturbance affects all of the ecosystem carbon pools, and the rate of their recovery to pre-disturbance levels is different between C pools and geographically (Bradford et al., 2008; Pregitzer and Euskirchen, 2004). For example, disturbances affect the amount of carbon in coarse woody debris and the

Published by Copernicus Publications on behalf of the European Geosciences Union. 
forest floor, causing these pools to shift between sources and sinks over time.

In this paper we present a forest age map of the US and Canada, describe our approaches to develop this map and a companion map of standard deviation for age estimates that can be used for evaluating uncertainty. We discuss how such a map may be used with inventory data for analyzing carbon management opportunities and for other modeling applications. Forest age, implicitly reflecting the past disturbance legacy, is a simple and direct surrogate for the time since disturbance and may be used in various forest carbon analyses that concern the impact of disturbances. By combining geographic information about forest age with estimated C dynamics by forest type, it is possible to conduct a simple but powerful analysis of the net $\mathrm{CO}_{2}$ uptake by forests, and the potential for increasing (or decreasing) this rate as a result of direct human intervention in the disturbance/age status. The biological potential of afforestation, reforestation, and forest management to offset fossil fuel emissions may be estimated with knowledge of the area available for the activity and estimated changes in ecosystem $\mathrm{C}$ by age. This kind of analysis is regionally and globally significant with respect to managing the carbon cycle. According to the latest IPCC report, the potential of global forestry mitigation measures may be as high as $13.8 \mathrm{Pg} \mathrm{CO}_{2} \mathrm{yr}^{-1}$ at carbon prices of $\$ 100 \mathrm{t}^{-1} \mathrm{CO}_{2}$ (Nabuurs et al., 2007). We also briefly described how such information can be applied in large-scale carbon modeling, using both land-based biogeochemistry models and atmosphere-based inversion models for improving the accuracy of simulated carbon dynamics.

\section{Data and methods}

To generate the age map, we integrated remote sensing data with the age information from forest inventories, disturbance datasets, and land-use/land cover change data. Because Canada and the US have different systems and approaches to collect and manage forest and land data, different approaches were used to produce spatial forest age information for these two countries (Table 1).

\subsection{Approach for Canada}

\subsubsection{Inventory and disturbance data}

In Canada, the national forest inventory (CanFI) is compiled about every five years by aggregating provincial and territorial forest management inventories (www.nrcan-rncan.gc.ca). Stand-level data provided by the provincial and territorial management agencies are converted to a national classification scheme and then aggregated to ecological and political classifications. The data used for this study were derived from the dataset developed by Penner et al. (1997), which was the gridded data at $10 \mathrm{~km}$ resolution and originally compiled from Canada's
Forest Inventory (CanFI) 1991 (1994 version) (Lowe et al., 1996). The data also include the forested area-fractions of age classes $(0-20,21-40,41-60,61-80,81-100,101-120$, 121-140, 141-160 and older). Since the inventory data was outdated, we used more recent remote sensing data to update the age information (only about 55\% of the total forest area of Canada is inventoried; unmanaged lands are not inventoried).

Historical fire data, based on the Canadian Large-Fire Data Base (LFDB), were compiled from datasets maintained by provincial, territorial and federal agencies (Amiro et al., 2001). The dataset provides polygons mapped in a Geographical Information System (GIS), which delineates the outlines of fires and associated attribute information, such as fire start date, year of fire, fire number, and final area burned. The dataset includes 8,880 polygons of fire scars larger than 200 ha distributed across much of the boreal and taiga ecozones, going back as far as 1945 in some areas (Stocks et al., 2003). The LFDB includes fire records generally for 19591995.

\subsubsection{Remote sensing and age distribution}

Satellite imagery was used to supplement data from inventory and LFDB to complete a Canada-wide forest stand age map in 2003. The data from the VEGETATION sensor onboard the SPOT4 satellite were used in this study. The angular normalization scheme developed for AVHRR (Chen and Cihlar, 1997) was applied to VEGETATION 10-day cloudfree synthesis data from June to August 1997. Ratios of shortwave infrared (SWIR) to NIR in these 9 images, named as the disturbance index (DI), were averaged for each pixel to produce a single ratio image for the mid-summer. The averaging process was necessary as SWIR signals are sensitive to rainfall events. Co-registered with LFDB data, the relationship between the mean SWIR/NIR ratio in the summer and the number of years since the last burn (Amiro and Chen, 2003) was used to develop an algorithm for dating/mapping fire scar areas. The dating algorithms have accuracy of $\pm 7 \mathrm{yr}$ for scar ages smaller than $25 \mathrm{yr}$ (Amiro and Chen, 2003). The satellite imagery from VEGETATION-SPOT were used to develop the fire scar maps of $25 \mathrm{yr}$ from 1973-1997, including the fire scars that were not included in LFDB. The results show that the total disturbed area in any five-year period is within $10 \%$ variation of the total reported by Kurz and Apps (1995). The VEGETATION data were also used to extend the fire record of LFDB from 1995 to 2003 by detecting burned areas annually.

A map of forest stand age for 2003 was created using the combined information from forest inventory, fire polygon data and remote sensing and a multi-stage approach. For simplicity, forest regrowth is assumed to start immediately after disturbance, so the age of forest in a burned area is assumed to equal the time since the date the fire scar was detected by remote sensing. The maps with fire scar dating were then 
Table 1. Comparison of data and methods used to develop forest age maps for Canada and the US.

\begin{tabular}{ll}
\hline Data/methods & Canada \\
\hline $\begin{array}{l}\text { Forest inventory } \\
\text { data }\end{array}$ & $\begin{array}{l}\text { National Forest Inventory (CanFI), collected mostly in } \\
\text { late 1980's by provincial and territorial agencies (Pen- } \\
\text { ner et al., 1997). The inventory data were gridded to } \\
10 \mathrm{~km} \text { resolution with areal fractions of age classes in } \\
\text { each grid (Chen et al., 2003). The data are only for } \\
\text { managed forests ( 55\% of total forest) with exclusion } \\
\text { of northern boreal forests. www.nrcan-rncan.gc.ca }\end{array}$ \\
& $\begin{array}{l}\text { SPOT-VEGETATION, 10-d cloud-free synthesis data } \\
\text { of June-August in 1997, for detecting fire scars from }\end{array}$ \\
Remote Sensing & 1973-1997. The same data of 1998-2003 are used for \\
newa fire scar detection for the period. & Canadian Large-Fire Data base (LFDB) covered 1959- \\
Supplementary & 1995, some areas back to 1945, with polygons (8880) \\
of fire scars larger than 200 ha, including outlines of & fires and attributes of date, year, fire numbers, and area \\
burned.
\end{tabular}

Methods of processing data

Map resolutions

Uncertainties and major error sources

Issues of concern for users

Website of

product (4) For unmanaged forests in the far north, undisturbed areas are filled with the average age $(75-120 \mathrm{yr})$ depending on the disturbance occurrence interval in each ecoregion.

$1 \mathrm{~km}$

Relatively high uncertainty; outdated, inconsistent and coarse resolution inventory data; poor and incomplete data of unmanaged north boreal forests; and errors introduced by remote sensing data and fire scar dating algorithm.

(1) Inconsistent inventory data collected from different years and outdated; (2) poor data of unmanaged northern boreal forests and inaccuracy of forest ages older than $60 \mathrm{yr}$ (beyond the earliest fire scar data can detect); and (3) remote-sensing based fire scar-dating algorithm can't separate disturbances of fires and insect outbreaks

\section{The US}

National Forest Inventory Analysis (FIA), collected periodically (every 5-6 yr, currently annual), at $\sim 150000$ sample locations. There are over 100000 data points for this study. FIA data include stand age with mostly one condition (even or average age), or 2-3 conditions of multiple ages (uneven-aged). Alaska has incomplete data. www.fia.fs.fed.us

NASA Landsat Ecosystem Disturbance Adaptive Procession System (LEDAPS). Disturbed areas between 1990 and 2000, $500 \mathrm{~m}$ pixels with fractions of disturbed areas summarized from mosaics at $28.5 \mathrm{~m}$ resolution.

Monitoring Trend in Burn Severity (MTBS), with burning severity values (1-4) and fire perimeters. Four states in the western US were selected for this study, which include 1405 fire events in 1987-2001.

Areas of annual regenerations between 1990 and 2000 were compiled from FIA data

(1) Developed age polygons based on FIA plot stand ages and assigned ages to $1 \mathrm{~km}$ (or $250 \mathrm{~m}$ ) grid cells; (2) Used TM/ETM scenes from LEADAPS to develop reflectance ratios (SWIR/NIR), i.e. disturbance index (DI), for 1990 and 2000. DIs were normalized and the differences (NDDIs) were used for detecting disturbances and making a disturbance map, which was validated using MTBS data;

(3) The FIA data of forest regeneration areas were forced to establish the relationship with the disturbed areas in each county; and used to find a threshold NDDI of for separating disturbances that occurred in 1991-1995 and 1996-2000;

(3) Converted the disturbance dating to an age map of young regeneration forests for age groups of $0-5$ and 6-10 yr;

(4) Young forest ages were superimposed on top of the Voronoi data to replace values of grid cells in the FIAbased age map. https://fsplaces.fs.fed.us/registration.nsf/Update?OpenForm\&login
$1 \mathrm{~km}$ and $250 \mathrm{~m}$

Relatively low uncertainty; biases of FIA stand age samples; averaging ages of uneven-aged forests in developing age polygons; inconsistency of acquisition dates from LEDAPS dataset for developing DIs for year 1990 and 2000; and errors from the algorithm dating by using FIA data to set the thresholds.

(1) Metadata approach, ages of uneven-aged forests were averaged; and (2) landscape disturbances that occurred before (or after) 1990s were not processed in this study and the effects could be missed in the age map if the inventory data did not cover the disturbed areas this could be a particular problem for the western US. 
used to replace the age data in the gridded inventory data. Fire polygons in the LFDB provided data for the northern boreal regions (unmanaged forests without inventory data), but only included large fires over the period of 1945 to 1995 (for dating the forests that are about younger than $60 \mathrm{yr}$ in 2003). Remote sensing imagery was further used to fill in the data gaps both in space and time. Annual forest burned area maps for years between 1973 and 2003 were constructed by the approaches described previously. However, the older age classes $(>25 \mathrm{yr})$ in the inventory are unchanged because we assumed that the inventory age-class data were correct for all grid cells that were not disturbed after 1973. In the combination of these three types of data, a $10 \times 10 \mathrm{~km}$ grid cell in the forest inventory was divided into 100 pixels at $1 \mathrm{~km}$ resolution. Pixels of different age classes were replaced by the fire polygons of known dates or by recent fire scars if detected by remote sensing. For the other undisturbed areas (not identified by fire scars and remote sensing) of the managed forests, pixels were randomly assigned with ages older than $26 \mathrm{yr}$, based on the area fractions in each age class reported in the inventories (after adjusted to the fractions of areas dated by remote sensing and fire scars). For the unmanaged forests in the far north, the limited inventory data indicated that most of forests are less than $120 \mathrm{yr}$. Thus, pixels were assigned with the average age (75-120 yr) depending on the disturbance occurrence intervals in each ecoregion that were used to estimate an average life span of forests (because forest ages younger than the age class of $61-80 \mathrm{yr}$ are supposedly identified by fire scars and remote sensing, and there were no other disturbances such as harvesting occurred in unmanaged forests).

\subsection{Approach for the US}

\subsubsection{FIA age information and disturbance data}

Development of the age map for the US is based primarily on field sampling by the Forest Inventory and Analysis (FIA) Program, a continuous inventory and assessment of US forests (Bechtold and Patterson, 2005). This national inventory provides periodic estimates of area, timber volume, tree biomass, growth, mortality, and harvest of wood products (Smith et al., 2001). The inventory also characterizes important forest attributes such as forest type, tree density, and stand age. Most forests of the US are sampled, except for some remote areas where only partial inventories have been conducted, most importantly Alaska. Alaska is currently being inventoried and comparable data may be available within a decade. The FIA estimates are based on tree measurements from a very large statistical sample (more than 150000 sample locations), and mathematical models to estimate forest attributes such as biomass (Birdsey and Schreuder, 1992). Stand age is estimated at sample plots by examining tree rings from cores of selected trees. Determination of stand age can be an inexact process because only one or a few trees, selected to represent the average age of the sample area, are cored. Over 100000 data points were used in this study. We also compiled forest regeneration areas for 1990-2000 from FIA database for the age-dating purpose.

\subsubsection{Remote sensing and age distribution}

The NASA Landsat Ecosystem Disturbance Adaptive Processing System (LEDAPS) (Masek et al., 2008) applied remote sensing data, particularly Landsat TM/ETM data over the decades, to detect land disturbances and forest cover changes. LEDAPS produces disturbance maps at $28.5 \mathrm{~m}$ resolution for selected areas and at $500 \mathrm{~m}$ resolution for the whole of North America. It also provides the fraction of disturbed area within each $500 \mathrm{~m}$ pixel by summarizing the $28.5 \mathrm{~m}$ resolution information. In addition, the reflectance data for North America at $500 \mathrm{~m}$ resolution were also available for this analysis. We used atmospherically corrected $500 \mathrm{~m}$ North America surface reflectance mosaics from LEDAPS (1990 and 2000) to extract the disturbance information, through pair-wise comparison of reflectance data. The disturbance indices (DIs), the ratios of the shortwave infrared (TM band 5) to near infrared (TM band 4) reflectance (Amiro and Chen, 1993), were developed for 1990 and 2000 and normalized. The DI is higher following disturbances, then decreases as vegetation density increases towards the pre-disturbed status. The differences of normalized DIs (NDDIs) were used for detecting disturbances or forest regrowth (i.e. a positive value indicates disturbance), and making disturbance maps. The Monitoring Trends in Burning Severity (MTBS) data (http://mtbs.gov/index.html) were used as a reference to assess the accuracy of forest disturbance maps (He et al., 2011). The MTBS is mapped at $30 \mathrm{~m}$ resolution using the differenced Normalized Burn Ratio (dNBR). The data from 4 states of the western US (California, Idaho, Oregon and Washington) were selected for accuracy assessment, composed of 1405 fire events (greater than $4 \mathrm{~km}^{2}$ ) for 1987 2001.

The average stand ages of FIA plots were used to develop the age map using Voronoi polygons. Voronoi polygons show the entire area around a plot location that it is nearest to its location. These can be assumed to represent forest stands and their respective ages around each FIA plot. This method works well in high data density areas where there is high spatial coverage of FIA plot locations (East Coast) and not as well when there is low spatial coverage of plot locations (Oklahoma). The polygon data were assigned to grid cells at $1 \mathrm{~km}$ resolution and then adjusted to the 2003 USFS Forest Type map (Ruefenacht et al., 2008). The forest ages range broadly from young growth in the southeastern region $(\sim 10 \mathrm{yr})$ to old growth in western coasts $(\sim 900 \mathrm{yr})$.

Additional change detection for disturbed areas by the DIbased approach does not provide information about the timing of disturbance within the 10-year time window; however, the variation of NDDIs is generally related to disturbance 

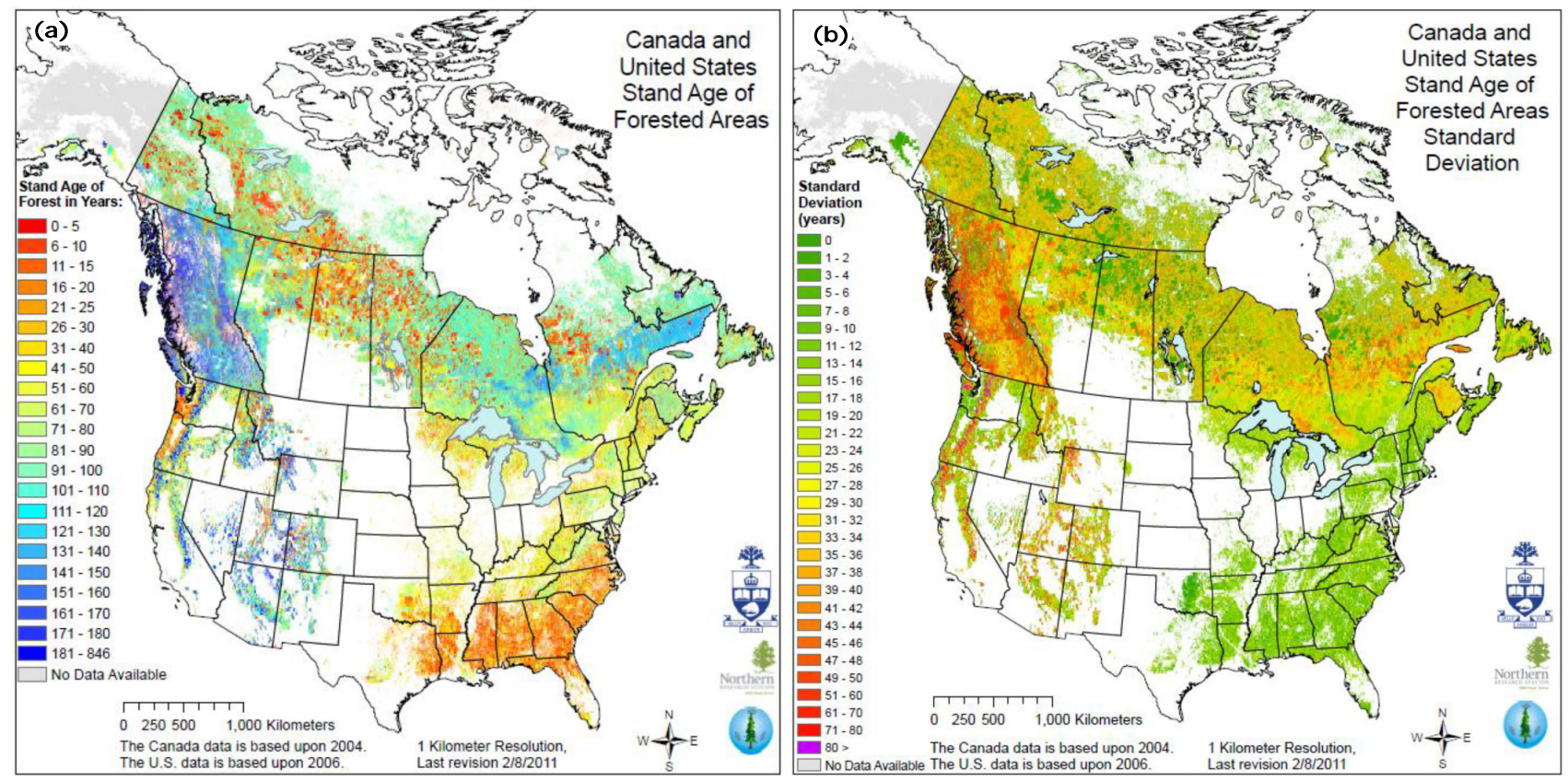

Fig. 1. (a) Forest age distribution in North America (excluding Alaska and Mexico), which was developed by combining forest inventory data (of US and Canada) with several remote sensing based disturbance data sources. (b) The standard deviations of forest ages that characterize uncertainty in the age map (a).

time, being higher for newly disturbed areas. Assuming forest regrowth starts immediately after disturbance, we developed an algorithm to force total regenerated forest areas of the FIA statistics to relate to the total disturbed areas within each county (He et al., 2011). The NDDI values of pixels in each county were sorted in descending order and a threshold NDDI was chosen based on the fractions of regenerated forest areas in two five-year groups (i.e. 1990-1995 and 19962000). The threshold NDDI was used to separate pixels of disturbed areas into two age groups of young forests (1-5, and 6-10 yr) (He et al., 2011). Finally, the young forest ages were used to overlay and modify the inventory-based forest ages to produce the age map.

\subsection{Uncertainty and major error sources of the age map}

For the forest age map (Fig. 1a), we also developed a standard deviation (std) map (Fig. 1b) for quantifying uncertainty. The std map provides a useful uncertainty measure for users to apply the age map in their studies. Because the data sources of Canadian and the US components are different, the methods for calculating std are also different. For the US, with high quality and massive forest inventory data, we have developed the age map at $250 \mathrm{~m}$ resolution based on age polygons generated from plot data using the GIS approach (Pan et al., 2010). The standard deviation for each $1-\mathrm{km}$ grid cell is calculated based on 16 sub-pixels. The deviation reflects the uncertainty of spatial heterogeneity in age distribution and the GIS approach for interpolating plot data.
High uncertainty occurs in the rocky mountain regions and the west coast because forest age cohorts of young and longlived trees are mixed over the landscape. Most of the deviations in the eastern US are around $10 \mathrm{yr}$, indicating more homogeneous and young forest age structures (Fig. 1b).

For the Canadian component of the age map, the std was estimated using a "moving window" approach for each center pixel with 8 neighboring pixels. The deviation reflects the spatial heterogeneity of age distribution but at a much coarser resolution than the US data, revealing uncertainty in those undisturbed forests where the age fractions from the inventory data map $(10 \times 10 \mathrm{~km})$ were randomly assigned for down-scaled 1-km pixels. The least uncertainty is for those grid-cells where forest ages were identified by the fire scar data and remote sensing. The highest uncertainty happens to the undisturbed forest areas in British Columbia, where a large discrepancy in age cohorts between young and old growth and the random age assignment in down-scaled pixels jointly cause the uncertainty to be around $50 \mathrm{yr}$ (Fig. 1b). Less than $1 \%$ of grid-cells located in the west coast of the US and British Columbia have high deviations greater than $80 \mathrm{yr}$, resulting from great spatial diversity of age mosaics in a neighborhood consisting of both newly generated young forests and long-lived old growth (Fig. 1a).

We provide a table to list major possible error sources and issues that users of the age map should consider in their applications (Table 1). The US map was based on high-density forest inventory data, but only incorporated the information 
of very recent disturbances (1990-2000). The Canadian map was based on older inventory data that was gridded at $10 \mathrm{~km}$ resolution and only covered managed forests $(55 \%$ of total forests). However, historical fire polygon data (major disturbances for Canadian forests) over five decades provided valuable data, together with remote sensing, for detecting the perimeters and timing of disturbed forests. Thus, the major error sources or inaccuracy for the Canadian age map are from older, inconsistent, and coarse resolution inventory data, incomplete data of unmanaged northern boreal forests, and problems related to the poor spatial resolution of the inventory data (it was necessary to randomly assign ages to the down-scaled $1 \mathrm{~km}$ grid cells based on the inventoried fractions of age-classes in the $10 \mathrm{~km}$ grid cells because the exact location of each class within each grid cell is unknown). In addition, the remote sensing based approach also introduces errors in the algorithm dating ( $\pm 7 \mathrm{yr}$ ) (Chen et al., 2003). For the US age map, errors could be derived from inaccurate determination of age at FIA sample plots, and from the use of average ages for uneven-aged stands when developing age polygons. For identifying the impact of recent disturbance on forest age pattern, the use of LEDAPS data included errors from inconsistency in acquisition dates for developing DIs for years from 1990 to 2000. Uncertainty can also be associated with a relatively arbitrary approach to algorithm dating by using the FIA data of forest regeneration to choose the spectral thresholds.

\section{Age structure and disturbance legacy of North American forests}

The forest age map (Fig. 1a) developed in this study shows the pattern of forest age structure in temperate and boreal areas of North America. We regrouped age classes for mapping but the original age data for users preserve their variations (Table 1 includes the website address of the data). Although the approaches to develop forest age maps in Canada and the US are not exactly the same, the map results show consistent and smooth patterns across the boundaries between these two countries. Natural and human forces over the last two centuries together have shaped the age structure of forests in the US (Fig. 2) and Canada today (Birdsey et al., 2006; Kurz and Apps, 1999). Due to geographical features, land-use history, harvesting, and disturbance regimes, Canada in general has older forests than the US although there are some very old forests in the US. Pacific coast ( $\sim 900$ yr) For example, $43 \%$ of forests in British Columbia are defined as old growth with ages between 120 and $200 \mathrm{yr}$, but there are large patches of younger forests $(41 \%)$ in the early stages of recovery from wildfire and harvesting (BC Ministry of Forests, 2003). In contrast, forests in the Southeastern US have a distribution of younger age classes because of intensive management and harvesting for wood products. The regional histograms summarized from the areas of age-map pixels provide more de-

\section{Drain on the Sawtimber Stand}

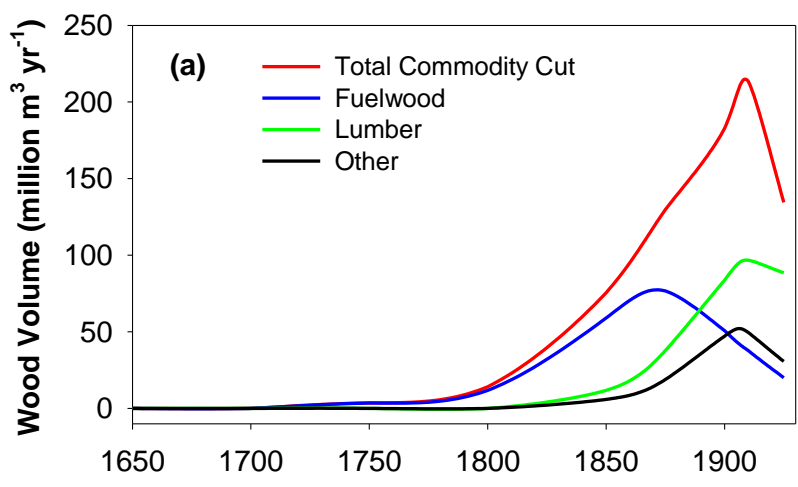

Wood Losses by Other Disturbances

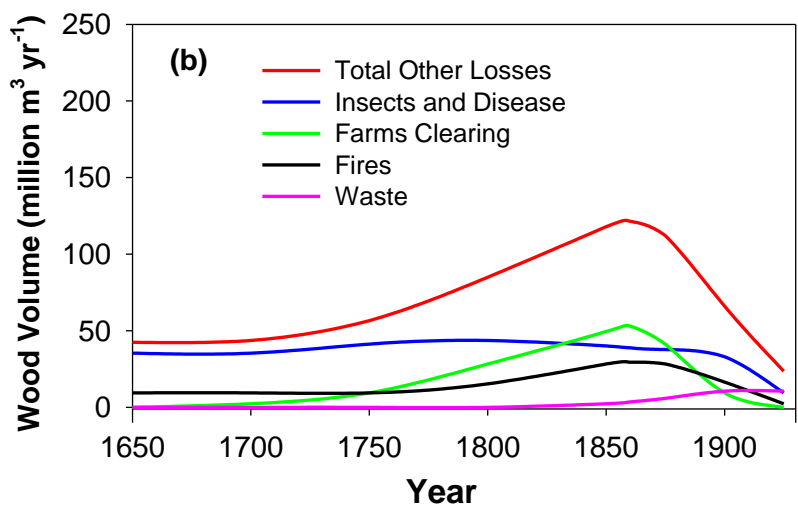

Fig. 2. Impacts of disturbances on forests in the past: (a) Drain on the US Sawtimber Stand, 1650-1925 (unit: million cubic meters per year based on sawtimber volume); and (b) wood losses affected by other disturbances (based on the data from Birdsey et al., 2006).

tailed data of age structures and ranges in regions of the US and Canada (Figs. 3, 4 and 5). We illustrate how these regional forest age structures implicitly represent the land disturbance legacy from the past, and also relate the age patterns with land-use and disturbance history to contrast the past human and natural causes.

\subsection{The US Northeast, Northern Lakes and Northern Plains regions}

Forest age classes in the US Northeast, Northern Lake, and Northern Plains regions have age distributions with the majority of areas falling into the dominant middle-age brackets of 50-80, 40-70, and 40-70 respectively (Fig. 4). Forest types in these regions are composed of northern hardwood and coniferous types including maple-beech-birch, aspenbirch, elm-ash-cottonwood, oak-hickory, spruce-balsam fir, white-red-jack pine, and mixed oak-pine forests. The average life-span of forests in these regions is approximately $130 \mathrm{yr}$ to $200 \mathrm{yr}$ or more as indicated by the oldest sampled forests (Fig. 4). From the eastern coast towards the northcentral inlands, species composition gradually changes from 

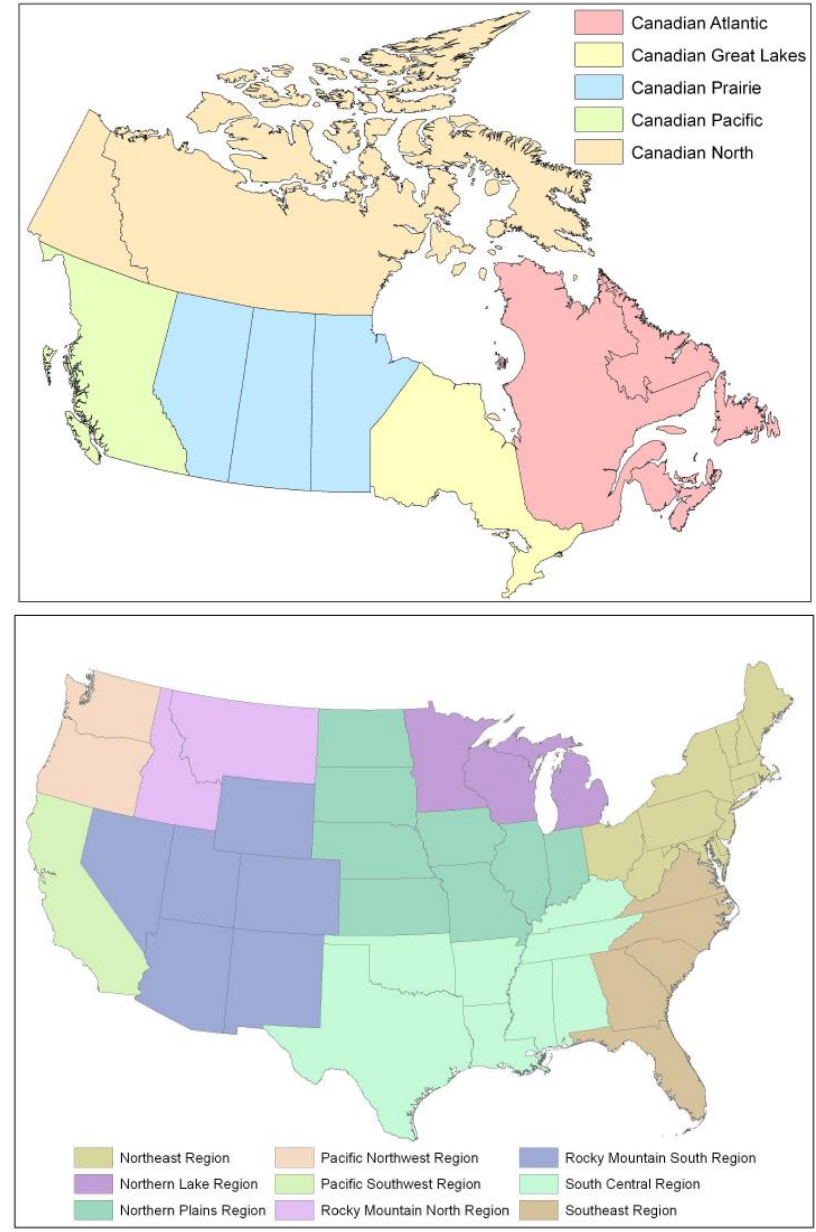

Fig. 3. Forest regions in Canada and the United States (Alaska is not shown here).

more maple-beech-birch, oak-hickory, and oak-pine to more aspen-birch and spruce-fir because of climate factors. However, roughly a decadal lag in shifting dominant forest age groups from the northeastern to the northern lakes and northern plains reflects the natural recovery of forests from westward agricultural clearing and abandonment and the pattern of forest harvest in the regions in the early 20th century (Fig. 4; Fedkiw, 1989; MacCleery, 1992). A lower representation of the age groups older than $80 \mathrm{yr}$ reflects the heavy harvest in the early 20th century (compared to the Canadian Atlantic Maritime region). Forests in these regions have potential to reach dominant ages of 100-120 yr old or more in next four to five decades. There are also indications of shifting species composition from white-red-jack pine types to deciduous Maple-beech-birch and oak-hickory types (Birdsey and Lewis, 2003) as a result of natural succession. Lower representation of young forests is typical for middle-aged forests that are not mature enough to create gaps for the next wave of regeneration.

\subsection{The US Southeast and South Central regions}

Forests in the Southeast and South Central regions are dominated by young growth and have shorter average life-spans of approximately $80-100 \mathrm{yr}$, although some are as old as $\sim 180$ yr (Fig. 4). Forests in the region are mostly composed of loblolly pine, slash pine, oak-pine, oak-hickory, oak-cumcypress, and elm-ash-cottonwood, with slightly more deciduous types than coniferous types in the southeast region and much more deciduous types towards the south central region. In the first half of the 20th century much of the Southern forest was cutover and frequently burned (Larson 1960). Afterwards, large areas of the southeast and south central regions were converted to short-rotation pine plantations, mostly loblolly and shortleaf pines. These plantations are routinely harvested and replanted, which results in relatively evenly-distributed age groups less than $60 \mathrm{yr}$ old for more than $80 \%$ of the forested area (Fig. 1a). Few stands reach more than $80 \mathrm{yr}$ old (Fig. 4). Areas that are not in plantation forestry are still harvested frequently; therefore other forest types are also maintained in a relatively young age pattern. In short, the southeast and south central forest age patterns strongly reflect the impacts of industrial forestry and plantation practice.

\subsection{The US Rocky Mountain north and south regions}

Forests in the Rocky Mountain regions (north and south) have totally different age structure patterns compared with the Eastern US. (Fig. 4). The forests are dominated by Douglas fir, fir-spruce, mountain hemlock, Lodgepole pine, and Ponderosa pine. These mountain types of forests generally have much longer life-spans than the forests in the East. Many are up to $200 \mathrm{yr}$ old and some even reach the $450 \mathrm{yr}$ mark. In the Rocky Mountain north region, forests ranging in age from $70-100 \mathrm{yr}$ are dominant, and then decline gradually with a long tail to the distribution (note that different scales were used in the age histograms). A large component of young trees (Fig. 4) displays a regeneration pattern in old forests that become susceptible to natural mortality and disturbances and often open large areas or gaps for regeneration. However, there is a small area of forests in age groups 20-60 yr, the consequence of fire suppression for more than half a century, which reduced wildfires and maintained dense stand structure that resulted in low understory recruitment (Donnegan et al., 2001; Gallant et al., 2003; Keeling et al., 2006). A high peak of age groups in the $70-100$ yr classes reflects the more usual stand-replacing disturbances that occurred before fire suppression. In the Rocky Mountain south region, forests tend to be older than in the northern region, with much higher components of old-growth forests and a longer life-span of $50 \mathrm{yr}$ more (Figs. 1a and 4). The dominant age groups are from $80-120 \mathrm{yr}$. There are periodic evenly distributed age groups distinct from adjacent age groups, reflecting periods of disturbances from fires or insects that left 


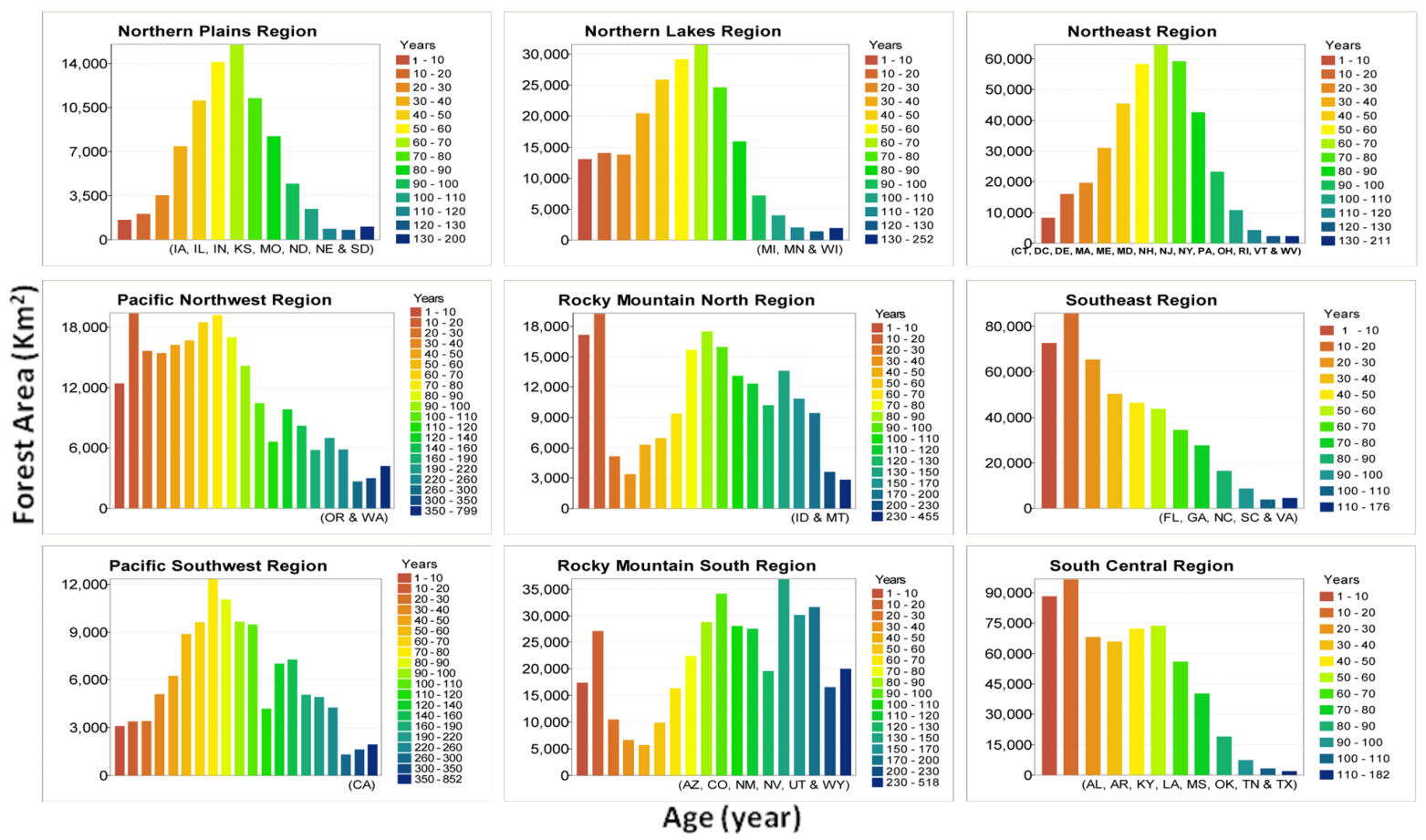

Fig. 4. The forest age distributions in different regions of Continental US (the histograms are placed in this figure as much as possible corresponding to their geographical positions).
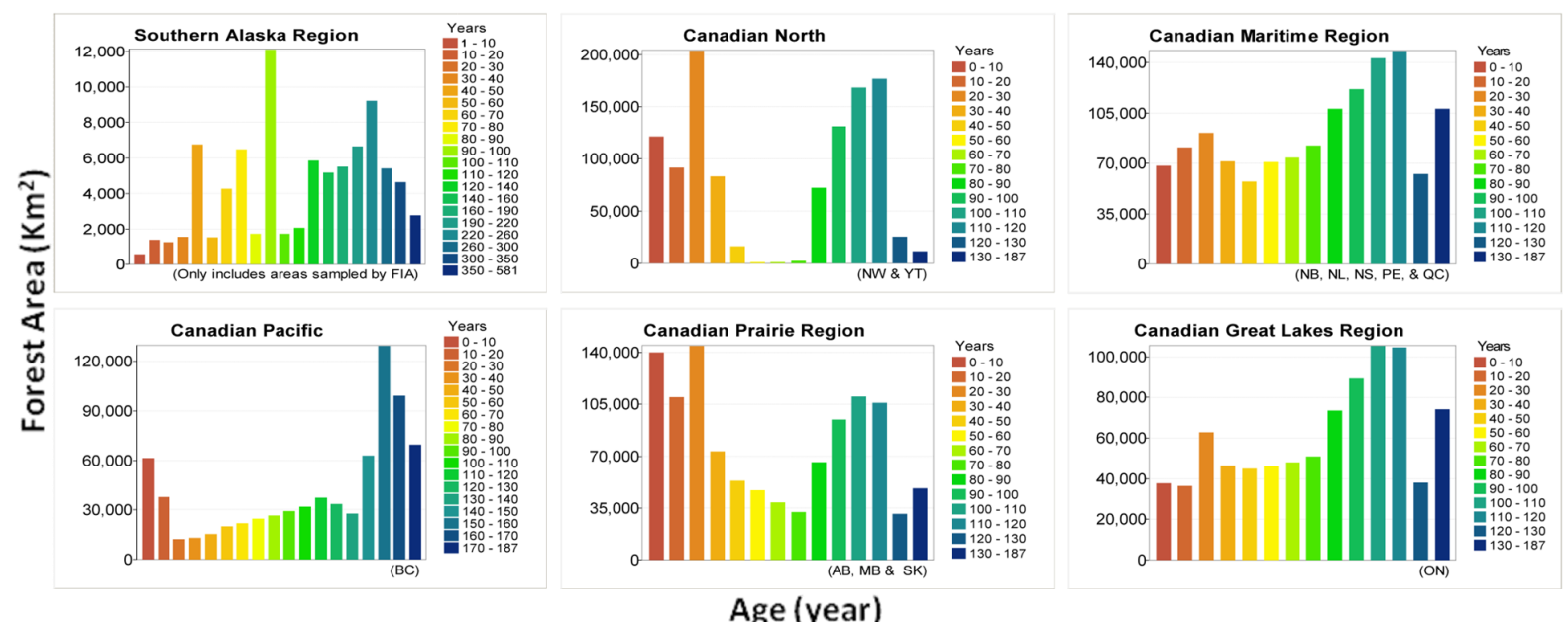

Fig. 5. Forest age distributions of the Southern Alaska of the US and regions of Canada (the histograms are placed in this figure as much as possible corresponding to their geographical positions).

only forest fragments, and periods of logging as the region was settled. There is less forest area below $20 \mathrm{yr}$ old compared with the northern region, which is expected for the southern forests with longer life-cycles and longer time taken for massive canopy openings to have new regeneration.
Because of the less accessible geography and recent lack of forest harvesting, a large component of intact old forests has survived. In general, the forest age structure of the Rocky Mountain regions reflects less human impacts compared with natural disturbance and succession. 


\subsection{The US Pacific Northwest and Southwest regions}

Forests in the Pacific Northwest and Southwest regions have the longest life spans of the US though the distribution of age classes tends to younger ages than in the Rocky Mountains (Fig. 4). Forest types in the Pacific West are similar to those in the Rocky Mountain regions, though with more local types such as western oak, Hemlock-Sitka spruce and Alder-maple. In the Pacific Northwest, trees can live up to $800 \mathrm{yr}$, while Pacific Southwest forests have trees up to $1000 \mathrm{yr}$ old (Fig. 4). An abrupt decline of forest age groups older than $100 \mathrm{yr}$ reflects pervasive harvest in late 19th century (Birdsey et al., 2006) during the westward expansion. In the Pacific West, more than half of old forest areas (more than $100 \mathrm{yr}$ ) vanished due to harvest and other disturbances. The area of old growth (generally, $200 \mathrm{yr}$ old or more) in 1992 was estimated to be about 10 million acres (Bolsinger and Waddell 1993), whereas in 1920 there was an estimated 40 million acres of "virgin forest" (Greeley, 1920). There is a distinct contrast in the age pattern of young forests between Pacific Southwest and Northwest regions. The Pacific Northwest region has much higher components of young forests due to more intensive regeneration of harvested lands for industrial forests (Figs. 1a and 4), whereas the forests of the Pacific Southwest region were more often left for natural recovery from disturbances of a century ago and show a natural succession pattern associated with low occurrence of young forests (Fig. 4), indicating that the forests in the region will take many decades to reach maturity.

\subsection{The US Southern Alaska region}

Inventory-based forest age information in Alaska is quite limited except for the Southeastern Alaska region. The forest age structure in the region is largely defined by natural disturbances and harvesting in the Tongass National Forest, the largest in the nation (US Forest Service, 2005). The forest longevity is comparable to the Rocky Mountain regions, with species composed of spruce-fir, Hemlock-Sitka Spruce, FirSpruce-Mountain Hemlock forests, and a small amount of aspen-birch. There are more old-growth forests than young forests (Fig. 5). There are a few age groups with irregularly higher proportion of area intervened with flatly distributed age groups- the uneven pattern that suggests some large periodic disturbances such as fires that happened across the landscape.

\subsection{Canadian Maritime region}

Forests in Canada are generally much less affected by human-induced disturbances. The forest age structure in the Canadian Atlantic Maritime region, compared to adjacent Northeast US (NE), fully reflects such a difference. After centuries of farming in this region, few remaining forests are older than $120 \mathrm{yr}$. However, the percentage of older forests is still much higher than that in the NE region (Figs. 4 and 5). Forest types and life-spans in this region are similar to the NE region though there are more boreal white and black spruce forests in the northern areas. The region is densely forested with second- and third-growth forests. The dominant forest age groups are from $80-120 \mathrm{yr}$ old, on average $40 \mathrm{yr}$ older than the NE region, reflecting the early agriculture abundance but without such a heavy harvest of second forests in the early 20th century as occurred in the NE region. Forests in this region also demonstrate a perfect natural successional pattern and the next wave of forest regeneration following various natural disturbances that affected mostly the boreal old growth forests located in the northern areas (Fig. 1a; Kurz and Apps, 1999; Williams and Birdsey, 2003).

\subsection{Canadian Great Lakes region}

This region is characterized by high coverage of forests and transitional coniferous boreal forests to broad-leaved deciduous forests. Forest types are similar to the US Northern Lakes region and the NE region. The forest age structure is similar to that in the Atlantic Maritime region, but marked by less remaining trees older than $120 \mathrm{yr}$ (Fig. 5). The succession pattern of forests is not as smooth as the maritime region with apparent traces of frequent natural disturbances, mostly in boreal forests in the north and northwest areas of the region with random disturbance patches and fire scars (Fig. 1a). Most forests younger than $80 \mathrm{yr}$ are distributed relatively evenly across age classes except for 20-30 yr old, regenerated after the last spruce-budworm outbreak that caused mortality of canopy trees (Williams and Birdsey, 2003).

\subsection{Canadian Prairie region}

The northern part of the Prairie region is populated with dense, closed boreal forests dominated by white and black spruce and other coniferous types, and also has a transitional zone with mixtures of broad-leaved trees and a wide range of trembling aspen that thins out into open and almost treeless Prairie in the south. The forest age structure bears some similarities to forests in the Great Lakes region (Fig. 5), showing the traces of agricultural abandonment in the later 18th century (Sisk, 1998), but with much less density of recovered forests and greater components of young forests. There are more natural disturbances in the boreal forests, which have a natural fire return interval of about 75 to $100 \mathrm{yr}$. Fires are the major cause of forest disturbances here because the region is dominated by coniferous trees and is also drier than other regions (Smoyer-Tomic et al., 2004). The dominant forest age groups are younger than $30 \mathrm{yr}$ forming the second wave of forest succession, and a relatively small area of forest is in the older age classes (Fig. 5). 


\subsection{Canadian North region}

The forests in this region represent the northern component of the Canadian boreal forest belt. A colder climate and shorter growing season nurture more spruce and larch, which dominate the landscape. Along the northern edge the forest thins into open lichen-woodland with trees growing farther apart and smaller in size as the forest stretches towards the treeless tundra. The forest age structure in the region is broken into two cohorts, trees younger than $40 \mathrm{yr}$ old, and trees between $80-120 \mathrm{yr}$ old (Fig. 5). Forest age structure in such a landscape is very much an indicator of periodic and highly variable fire disturbance cycles (Kurz and Apps, 1999). However, for this region, the data are particularly poor. The lack of forests aged from 40-80 yr indicates a lack of disturbance events for a long period, 1920-1960, which is unlikely. It is possible that this age cohort is missing because there is little data available for the region before 1959, and also because the average ages $(75-120 \mathrm{yr})$ were used to assign the pixels to age classes based on the disturbance occurrence intervals in each ecoregion (see Methods).

\subsection{Canadian Pacific region}

This region is characterized by the temperate rainforest, which is adapted to the steep cliffs and rugged coastlines of this area. The region has higher rainfall and fewer fires than other regions in Canada. As a result, trees in the temperate rainforest are often much older than those found in the boreal forest (Fig. 1a). Forests in the lower seaward slopes of the Coast Mountains include old growth cedar and Sitka spruce, while the steep hill slopes are habitat to western hemlock, balsam, red cedar and spruce. In the areas between the Rockies and the Central Plateau including several valleys, forest types resemble the coastal region, characterized by Douglas fir, western white pine, western larch, Lodgepole and ponderosa pine, and trembling aspen. Engelmann spruce and alpine fir are found in the subalpine region. The forest age structure shows a great amount of old-growth forests (>150 yr) still remaining in the region (Fig. 5). However, harvests between later 19th and early 20th centuries replaced old-growth forests with younger trees. Since then, forest age classes smoothly decline from $120 \mathrm{yr}$ to $20 \mathrm{yr}$ old, related to managed harvesting and reforestation in this most important timber industrial land of Canada. A high component of forests less than $20 \mathrm{yr}$ old is the result of combined effects, recent severe outbreaks of insects in the region (Kurz et al., 2008b), harvesting, and regeneration of new plantations.

\subsection{Summary of regional analysis}

The above analyses based on characteristics of the forest age map and the current forest age distribution patterns in different regions of the US and Canada clearly show the dependence of current age structure on disturbances of the past, both by natural events and human activities. The information is remarkably consistent with our knowledge about the landuse history and forest past in North America since European colonists arrived in North America (Sisk, 1998). Forest ages certainly carry the disturbance legacy and are excellent surrogates for addressing disturbance impacts on forests. Our analysis shows that forests in the US bear much deeper and broader human footprints than in Canada, that most forests in the US were disturbed in the last two centuries, except some inaccessible areas in the Rocky Mountains and Alaska, and that some old-growth remains in the Pacific Northwest and Southwest. In Canada, industrial timber harvest is quite intensive in some areas of boreal and temperate rainforests. However, because of Canada's immense forest lands and frequent and wide-spread natural disturbances, particularly wildfires, forested lands are distinctly marked by natural disturbances with the exception of the Pacific Region. On average in Canada, the annual burned area is more than three times the area of current annual industrial timber harvest, and the burned area is even more widespread in bad fire years (Stocks et al., 2003). Just the opposite is true for the US where the impact of timber harvest is several times that of the impact of natural disturbances.

\section{Application of forest age map in forest carbon studies}

Because forest disturbance and regrowth profoundly affect forest capacity for sequestering and storing carbon, our continent-wide spatial data of forest age distribution can be used for improving estimates of forest carbon stock and flux in North America, and can also be used as a reference for assessing the future forest carbon balance and potential, regardless of whether the estimation approach is empirical or model based. Though there are many possible applications of this valuable information to forest carbon studies, here we describe a few potential uses to provoke further ideas.

\subsection{Using the age map to analyze impacts of forest management on carbon sequestration}

Estimates of current carbon stocks and changes in carbon stocks at the landscape scale may be simply made by combining the age map with standard estimates of ecosystem carbon for different forest types and regions (Smith et al., 2006). Here we present an example of this kind of applications for the Northeastern US. This approach is likely only applicable to the US forests because high quality inventory data provide strong statistics of standard estimates of ecosystem carbon. In Smith et al. (2006), FIA data, a chronosequence approach, and statistical models are used to estimate carbon stocks of different carbon pools by forest type, region, age class, site productivity, and management intensity. When all of the carbon pools are added together, the change in carbon between age classes divided by the age interval ( 5 or $10 \mathrm{yr}$ ) is 
Table 2. Area (ha) by forest type and age class for the Northeast US.

\begin{tabular}{lrrrrrr}
\hline $\begin{array}{l}\text { Age } \\
\text { class }\end{array}$ & $\begin{array}{r}\text { Aspen- } \\
\text { birch }\end{array}$ & $\begin{array}{r}\text { Maple-beech- } \\
\text { birch }\end{array}$ & $\begin{array}{r}\text { Oak- } \\
\text { hickory }\end{array}$ & $\begin{array}{r}\text { Oak- } \\
\text { pine }\end{array}$ & $\begin{array}{r}\text { Spruce- } \\
\text { balsam fir }\end{array}$ & $\begin{array}{r}\text { White-red } \\
\text { jack pine }\end{array}$ \\
\hline $0-5$ & 6919 & 160831 & 124856 & 3538 & 29875 & 6150 \\
$6-15$ & 22281 & 769550 & 272056 & 5819 & 232631 & 20731 \\
$16-25$ & 36838 & 923075 & 982156 & 10950 & 316119 & 27775 \\
$26-35$ & 42019 & 1401188 & 789894 & 14738 & 274350 & 70763 \\
$36-45$ & 61769 & 2198769 & 2311050 & 43075 & 301919 & 140375 \\
$46-55$ & 55281 & 2609775 & 1404206 & 43775 & 358263 & 188044 \\
$56-65$ & 64006 & 3176638 & 3176706 & 58119 & 376831 & 239156 \\
$66-75$ & 51475 & 2755381 & 1456706 & 28519 & 389419 & 171313 \\
$76-85$ & 34200 & 2106606 & 2030619 & 32838 & 317606 & 106925 \\
$86-95$ & 18388 & 1192050 & 590188 & 7619 & 169494 & 60100 \\
$96-105$ & 6781 & 592019 & 617738 & 7338 & 107350 & 27213 \\
$106-115$ & 9200 & 221713 & 137263 & 2750 & 71056 & 12831 \\
$116-125$ & 3719 & 112081 & 66888 & 800 & 34444 & 3925 \\
$>125$ & 3550 & 131831 & 113656 & 369 & 48375 & 5863 \\
\hline Total & 416426 & 18351507 & 14073982 & 260247 & 3027732 & 1081164 \\
\hline
\end{tabular}

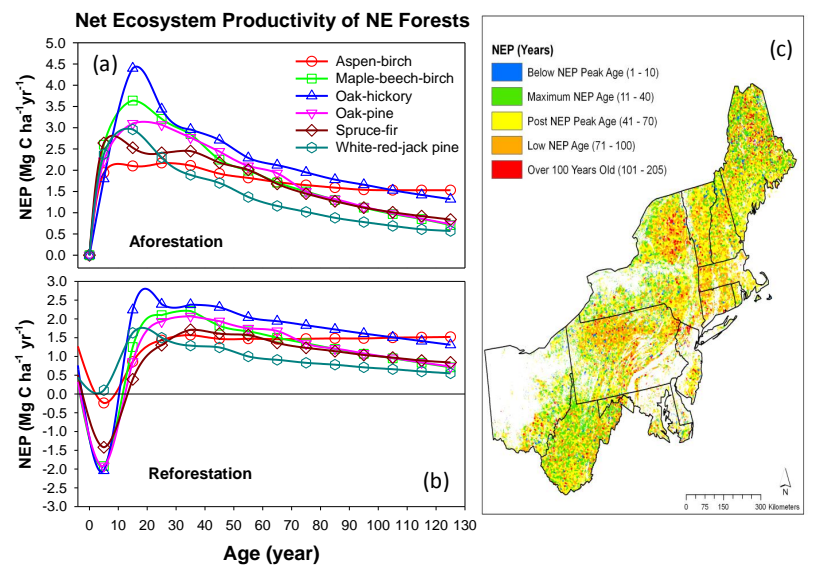

Fig. 6. Mean annual net ecosystem productivity of Northeast region forests based on forest inventory data: (a) from afforestation sites; (b) from deforestation sites, NEP loss from woody product is not counted in the initial year, and (c) Northeastern forests with different NEP levels related to age.

an estimate of average annual NEP $\left(\mathrm{MgC} \mathrm{ha}^{-1} \mathrm{yr}^{-1}\right)$ for the interval. When combined across all age classes, the resulting curve shows the pattern of NEP over time (Fig. 6a and b).

From the age map, we estimate the area by forest type and age (Table 2) and then multiply the estimated area of each category with the corresponding NEP to produce regional NEP estimates (Table $3 a$ and $b$ ). A regional NEP map can also be presented by co-registering the age map, forest type map and age-related NEP values (Fig. 7) (Pan et al., 2010). Because of uncertainty in the forest age map, the variance in NEP inherited from that source can also be evaluated. For the whole region, the uncertainty in NEP ranges from 2.3-

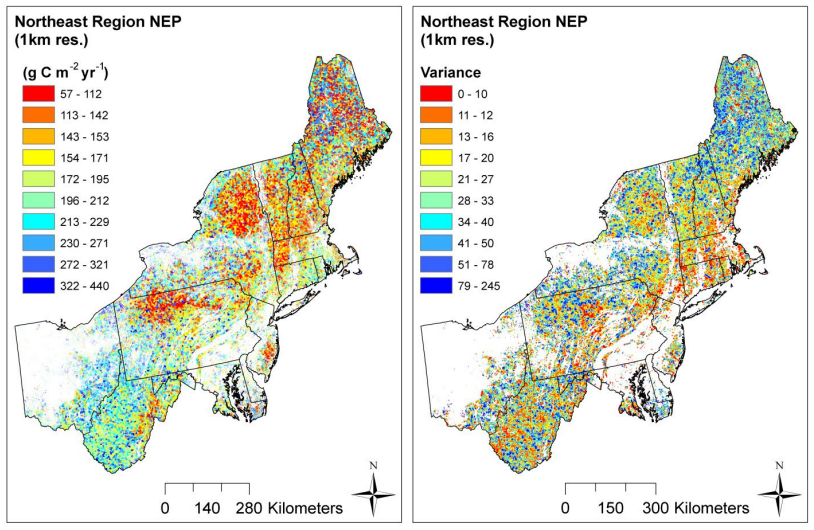

Fig. 7. Average Net Ecosystem Production $\left(\mathrm{gC} \mathrm{m}^{-2} \mathrm{yr}^{-1}\right)$ of the US Northeastern forests and the variation inherited from the age deviation.

8.9 $\mathrm{Tg} \mathrm{Cyr}^{-1}$, which is about $4-12 \%$ of the total accumulated NEP carbon (Table $3 \mathrm{a}$ and $\mathrm{b}$ ). However, the uncertainty in NEP is particularly higher in the northern part of the region (Fig. 7) where young forests and old forests are highly mixed (Fig. 6c), resulting from higher deviations in estimated ages.

On average, NEP is $1.35-2.19 \mathrm{MgCha}^{-1} \mathrm{yr}^{-1}$ in afforestation sites, and $0.88-1.57 \mathrm{MgC} \mathrm{ha}^{-1} \mathrm{yr}^{-1}$ in reforestation sites with some variation by forest type (Fig. 6a and b). These estimates compare reasonably well with measured NEP at flux towers at the Harvard Forest in Massachusetts and the Howland Forest in Maine (Barford et al., 2001; Hollinger et al., 2004), and regional modeling results 
(Ollinger et al., 2002). There is $25 \%-42 \%$ lower NEP (dependent on forest types) on reforestation sites that follow harvest or other disturbances because of the loss of carbon from forest floor and soils, which is different from afforested sites where soil carbon typically increases to recover depleted pools from previous agriculture use (e.g. Post and Kwon, 2000). In reforestation sites, post-disturbance NEP dynamics depend on disturbance types and slash treatment methods. However, our estimates of the reduced NEP reflect regional average patterns and are not specific to either industrial forestry or areas prone to natural disturbances. As a result, annual NEP in the New England forests under the current age structure is between $60-76 \mathrm{Tg} C$ which compares favorably with recent estimates of annual changes in carbon stocks from repeated inventories (US Department of Agriculture, 2008). In total, the carbon accumulation from reforestation sites is about $20 \%$ lower than afforestation sites; however we did not count carbon in harvested wood from the reforestation sites, which could largely compensate for the lower carbon accumulation in reforestation sites.

Forest age can be a good indicator of management opportunity. When compared with a standard growth curve, forest age can indicate whether the stand is aggrading or degrading, giving the land manager an indication of the kind of treatments that can be applied if the manager is interested in changing the rate of carbon sequestration or increasing the stock of carbon on a landscape. Continuing the previous example for New England, we show the deviation from maximum NEP for each forest grid cell of the Northeast and indicate whether this deviation is because the forest is younger or older than the age of maximum NEP (Fig. 6c). If the manager is interested in maximizing NEP, it may be determined that forests younger than the age of maximum NEP could be left alone because carbon sequestration will increase without any intervention, and that forests older than the age of maximum NEP may be considered for thinning to reduce stand density to an effectively younger age. If the manager is interested in increasing the stock of carbon on a landscape, the map may be used to identify forests that are already at high stocking levels and would require protection from disturbance, and to identify forest areas that could be left to grow older. As shown by the regional age distributions described in the previous section, some combination of maximizing NEP and maximizing $\mathrm{C}$ stocks is likely to emerge in practice over large regions, considering that forests are not only managed for carbon but also for many other purposes such as timber production and recreation. Note that in this simple exercise we are not recommending a specific approach to increase carbon sequestration or carbon stocks. A full assessment of management opportunities is much more complicated and needs to consider factors such as emissions and retention of $\mathrm{C}$ in harvested wood, the energy inputs for stand treatments, and impacts on soil $\mathrm{C}$, to name a few. Our results clearly show that after disturbances (referring to reforested sites) forests have reduced total NEP (Table 3) because of carbon losses in the earlier recovery stages. The age map combined with the mapped productivity provides a first-level spatial analysis of the state of the forest system, which may then be expanded to a full carbon accounting and management recommendations.

\subsection{Using the age map to improve carbon estimation by terrestrial models}

Process-based biogeochemical models are important tools to estimate terrestrial carbon budgets (Sitch et al., 2008). A very unique function of such "mechanistic" models is the ability in a diagnostic sense to interpret temporal and spatial patterns of forest $\mathrm{C}$ dynamics and partition the effects of various climatic drivers and different environmental variables, which are not always identifiable by experimental and observation approaches (Pan et al., 2009). Therefore, terrestrial carbon models can serve as powerful methods to integrate and expand our knowledge of complex interactive effects of multiple environmental changes on forest carbon dynamics. Terrestrial carbon models are continuously improving by reducing uncertainty in estimation and prediction, and by improving input data layers, model formulas and parameters (Pan et al., 2006).

Currently, many land-based terrestrial carbon models are not capable of reflecting the impact of land disturbances because spatially-explicit historical data at landscape scales is lacking. Therefore, most models represent ecosystem dynamics at equilibrium conditions (Canadell et al., 2007a). However, with the availability of spatial forest age data and its ability to simply represent historical disturbance legacy, we can improve terrestrial biogeochemistry models by using age cohorts and incorporation of forest growth curves (Fig. 6a and b), making the models capable of simulating forest regrowth dynamics as the consequences of the impact of land-use, human and natural disturbances (Pan et al., 2002), even if they may not able to separate direct and indirect effects.

In a Canada-wide forest carbon cycle study using a mechanistic ecosystem model with consideration of both disturbance (mostly fire) and lack of disturbance (climate, $\mathrm{CO}_{2}$ and nitrogen) effects, a forest age map compiled from forest inventory, large fire polygons and remote sensing played a central role in estimating the direct carbon emissions during the fire and regrowth after the disturbance (Chen et al., 2003). The improved terrestrial carbon models can also use the current forest age map to project the forest age structure over the next few decades following natural succession, and predict potential carbon sequestration capacity of forests in the near future, for better understanding of the role of forests in the entire global carbon cycle and addressing the recent concern about the possibility of terrestrial carbon sink saturation in the next few decades (Canadell et al., 2007b). In addition, because the data-based spatially-explicit estimates of NEP (Fig. 7) represent average carbon balances of forest 
Table 3a. Area-weighted NEP $\left(\mathrm{MgC} \mathrm{yr}^{-1}\right)$ by forest type for the Northeast US (based on the mean values of NEP $\left(\mathrm{MgCha}^{-1} \mathrm{yr}^{-1}\right)$ from afforestation sites.)

\begin{tabular}{lrrrrrr}
\hline $\begin{array}{l}\text { Age } \\
\text { class }\end{array}$ & $\begin{array}{r}\text { Aspen- } \\
\text { birch }\end{array}$ & $\begin{array}{r}\text { Maple-beech- } \\
\text { birch }\end{array}$ & $\begin{array}{r}\text { Oak- } \\
\text { hickory }\end{array}$ & $\begin{array}{r}\text { Oak- } \\
\text { pine }\end{array}$ & $\begin{array}{r}\text { Spruce- } \\
\text { balsam fir }\end{array}$ & $\begin{array}{r}\text { White-red } \\
\text { jack pine }\end{array}$ \\
\hline $0-5$ & 13423 & 418161 & 224741 & 7854 & 78870 & 14637 \\
$6-15$ & 46790 & 2801162 & 1197046 & 18039 & 588556 & 61364 \\
$16-25$ & 79939 & 2963071 & 3378617 & 33617 & 761847 & 63883 \\
$26-35$ & 88660 & 3993386 & 2338086 & 40824 & 672158 & 133742 \\
$36-45$ & 118597 & 4947230 & 6262946 & 105103 & 658183 & 238638 \\
$46-55$ & 100611 & 5193452 & 3215632 & 91928 & 720109 & 257620 \\
$56-65$ & 110090 & 5432051 & 6734617 & 112170 & 633076 & 277421 \\
$66-75$ & 849334 & 4133072 & 2840577 & 42779 & 564658 & 174739 \\
$76-85$ & 54378 & 2738588 & 3614502 & 43346 & 403360 & 94094 \\
$86-95$ & 28318 & 1335096 & 979712 & 8686 & 189833 & 46878 \\
$96-105$ & 10375 & 574258 & 945139 & 7265 & 108424 & 18777 \\
$106-115$ & 14076 & 188456 & 194914 & 2365 & 65372 & 7827 \\
$116-125$ & 5690 & 79578 & 88292 & 584 & 28933 & 2237 \\
$>125$ & 5432 & 93600 & 150026 & 269 & 40635 & 3342 \\
Total & 1525713 & 34891161 & 32164847 & 514829 & 5514014 & 1395199 \\
\hline Regional total & $76005763 \mathrm{Mg} \mathrm{Cyr}^{-1} \approx 76 \mathrm{Tg} \mathrm{C} \mathrm{yr}^{-1}$ & \\
\hline \multicolumn{7}{c}{}
\end{tabular}

Table 3b. Area-weighted NEP $\left(\mathrm{MgC} \mathrm{yr}^{-1}\right)$ by forest type for the Northeast US (based on the mean values of NEP $\left(\mathrm{MgCha}^{-1} \mathrm{yr}^{-1}\right)$ from reforestation sites).

\begin{tabular}{lrrrrrr}
\hline $\begin{array}{l}\text { Age } \\
\text { class }\end{array}$ & $\begin{array}{r}\text { Aspen- } \\
\text { birch }\end{array}$ & $\begin{array}{r}\text { Maple-beech- } \\
\text { birch }\end{array}$ & $\begin{array}{r}\text { Oak- } \\
\text { hickory }\end{array}$ & $\begin{array}{r}\text { Oak- } \\
\text { pine }\end{array}$ & $\begin{array}{r}\text { Spruce- } \\
\text { balsam fir }\end{array}$ & $\begin{array}{r}\text { White-red } \\
\text { jack pine }\end{array}$ \\
\hline $0-5$ & -1661 & -308796 & -254706 & -6793 & -42423 & 615 \\
$6-15$ & 19162 & 961938 & 609405 & 5004 & 90726 & 33792 \\
$16-25$ & 52678 & 1938458 & 2347353 & 21134 & 410955 & 41663 \\
$26-35$ & 65970 & 3096625 & 1879948 & 30508 & 469139 & 91284 \\
$36-45$ & 90800 & 4001760 & 5338526 & 83566 & 486090 & 174065 \\
$46-55$ & 81263 & 4358324 & 2864580 & 76606 & 562473 & 188044 \\
$56-65$ & 93449 & 4764957 & 6162810 & 97640 & 512490 & 217632 \\
$66-75$ & 75668 & 3719764 & 2665772 & 38216 & 478985 & 142190 \\
$76-85$ & 50616 & 2527927 & 3492665 & 39734 & 362071 & 83402 \\
$86-95$ & 27214 & 1275494 & 950203 & 8229 & 176279 & 42671 \\
$96-105$ & 10172 & 562418 & 932784 & 7045 & 104130 & 17961 \\
$106-115$ & 13892 & 184022 & 193541 & 2310 & 63240 & 7699 \\
$116-125$ & 5653 & 79578 & 87623 & 584 & 28933 & 2159 \\
$>125$ & 5396 & 93600 & 148889 & 269 & 40635 & 3225 \\
Total & 590272 & 27256068 & 27419392 & 404050 & 3743717 & 1046399 \\
\hline Regional total & $60459898 \mathrm{MgC} \mathrm{yr}^{-1} \approx 61 \mathrm{Tg} \mathrm{C} \mathrm{yr}^{-1}$ & \\
\hline
\end{tabular}


ecosystems over a landscape, they can provide the benchmark for the modeling studies (Pan et al., 2010). Based on the average NEP, it is a very reasonable to use an ecosystem model to generate annual anomalies and spatial effects of soils and climate on NEP by incorporating more driving variables, and to produce more spatially and temporally explicit NEP estimates (Chen et al., 2003).

\subsection{Using the age map to improve land constraints on atmospheric inversion models}

Several recent publications show a full analysis of the global carbon cycle with comprehensive consideration of carbon fluxes or stock changes in the atmosphere, ocean, and land (Le Quéré et al., 2009, Canadell et al., 2007b). In such analyses, the carbon exchange between the ocean and land surfaces with the atmosphere is estimated based on global transport inversion using observations of $\mathrm{CO}_{2}$ concentration in the atmosphere (Peters et al., 2007). Usually, inverse models are not well constrained because of an insufficient number of $\mathrm{CO}_{2}$ observation sites in the global monitoring network. Simulated carbon fluxes from lands and oceans with additional consideration of other surface observations are needed to provide constraints to the inverse modeling to obtain meaningful results. However, such inverse modeling could suffer great uncertainty from small-scale structure of the fluxes due to spatial heterogeneity, particularly for the regions lacking observations such as the tropical areas (Stephens et al., 2007).

One way to improve the inversion estimates is to provide better land-surface flux constraints. The a priori carbon flux fields from lands used for the inversion constraint are often obtained from ecosystems models validated at discrete sites using measurements such as eddy covariance (Deng et al., 2007; Peters et al., 2007). None of these surface flux fields used for constraining the inversions has so far considered forest carbon dynamics associated with forest age. The flux tower data have shown the obvious relationship between net ecosystem productivity (NEP) and forest stand age, indicating that the carbon flux over forests is closely related to forest age (Chen et al., 2003; Law et al., 2003). In order to capture the large scale regional patterns of the carbon flux associated with the disturbance and regrowth cycle and to estimate the first order effect of forest age on NPP and therefore NEP, the continent-wide forest age map is used for developing a forest age factor map (Fig. 8) (Deng et al., 2011), in which the age factor was calculated as a scalar based on a generalized NPP-age relationship (Chen et al., 2003). The generalized NPP-age relationship has a similar temporal pattern to those shown in NEP curves (Fig. 6a and b), when the heterotrophic respiration is assumed to be constant. The relationship is normalized against the maximum NPP value, so that the normalized NPP varies between zero and one. In the generalized NPP-age relationship, the age at which the maximum NPP occurs depends on the mean annual air tem-

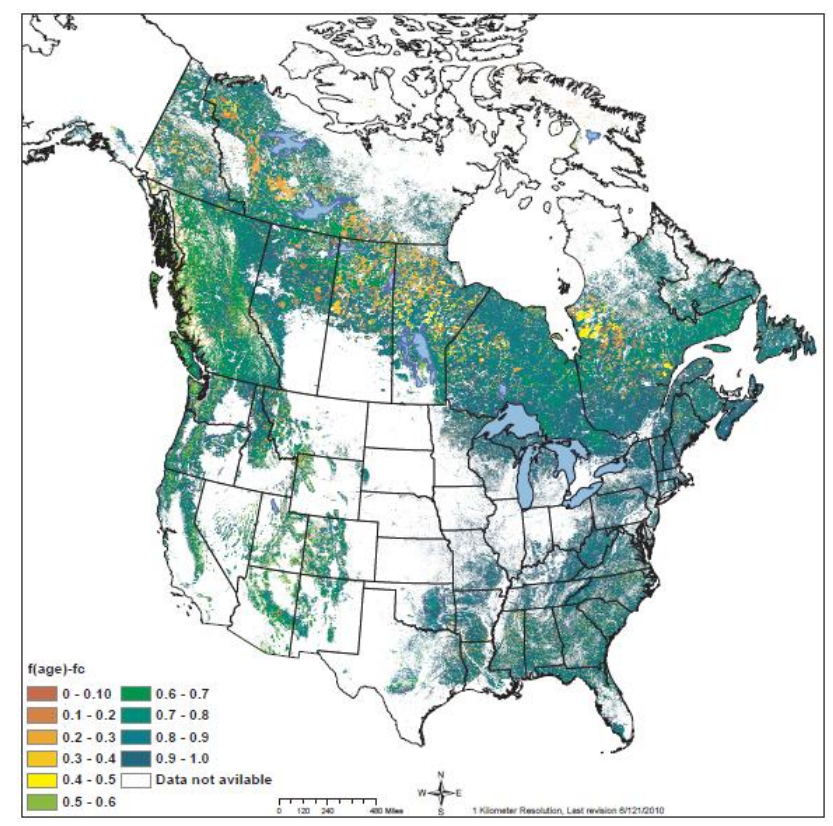

Fig. 8. Forest age factor derived from the forest age map (Fig. 1a) useful for constraining atmospheric inverse modeling of the biosphere carbon flux.

perature at each pixel (Chen et al., 2003), considering the fact that forests grow faster and reach the maximum NPP earlier under warmer climates. Other factors, such as precipitation, soil and topography, may influence the magnitude of NPP but are assumed to have no influence on the timing of the maximum NPP occurrence.

Figure 8 shows the distribution of the age factor (normalized NPP value) at the continental scale determined by the age map (Fig. 1a) and the mean annual air temperature (Deng et al., 2011). Low values (warm tone, i.e. yellow to red) indicate low productivity relative to its own life cycle either due to young or very old ages, where NPP is most likely smaller than the heterotrophic respiration $(\mathrm{NEP}<0)$. High values (cold tone, i.e. green to blue) suggests high productivity, where NPP is most likely greater than heterotrophic respiration $(\mathrm{NEP}>0)$. The fact that the overall distribution over the continent has a cold tone suggests that the forest age structure in North America is in favor of carbon sinks. The age factor map has been used to introduce a priori covariance as an additional constraint for an atmospheric inversion (Deng et al., 2011). The results show that at the subcontinental level, the inversed carbon fluxes are better correlated with the fluxes derived from the eddy covariance and MODIS when the age factor is used. As reliable $\mathrm{CO}_{2}$ concentration observation stations are still quite sparse and carbon fluxes from forests in various regions in the North America are quickly mixed by the atmosphere, the relative differences among the regions caused by their different age structures could help improve the spatial resolution of the atmospheric inversion. 


\section{Discussion and conclusion}

Ground-based and spatially explicit forest age data provide valuable information for improving forest carbon estimates, evaluating disturbance impacts, and predicting forest carbon sequestration potential in the next few decades as forests naturally proceed to reach maturity or start new succession. However, there are limitations of an age map for characterizing succession and carbon sequestration. Assigning an age to a forest is an inexact process. Trees in many if not most forests have different ages, so the assigned age is typically an average age unless there is a very distinct disturbance and regeneration activity such as a clear-cut followed by a plantation establishment (Bradford et al., 2008). Forests undisturbed for long periods of time tend to develop an uneven-aged stand structure as canopy gaps become filled with younger trees (Luyssaert et al., 2008). Many natural disturbances do not kill all of the trees in a forest stand, so the regenerating trees are often growing amongst a residual number of older trees. And natural regeneration may be a slow process such that the new trees may span a range of ages over several decades (Pregitzer and Euskirchen, 2004). Because of the nature of these disturbance and regeneration processes, there is a difference between age and time since disturbance (Bradford et al., 2008). In many cases, an observed tree age may be a poor predictor of time since disturbance, and depending on how this information is used in models, estimates of carbon stocks or fluxes may have significant errors.

Tree age data are not available everywhere in North America. Some regions are not very well covered by forest inventories, such as interior Alaska and the northern part of Canada. It is important to acknowledge the uncertainty and inaccuracy of the age map because of limitations of data sources and methodologies, particularly, inconsistency of age-related data between Canada and the US (Table 1). For instance, for the US, the disturbance information derived from remote sensing only covers $10 \mathrm{yr}(1990-2000)$, so the impact of disturbances that occurred before (or after) then could be missed in the age map if the inventory data does not pick up all disturbance effects. This can be particularly true for disturbance-prone regions in the western US where wildfires occur at a high frequency. In Canada, a big problem is for the massive area of northern boreal forests that have little ground-based inventory data to constrain the assignment of ages to pixels. Accordingly, the age map is only a metadata-based result, given the fact that the forest age is represented by a single value in a pixel of $1 \mathrm{~km}$ resolution that more likely contains a mix of ages. The map is most appropriate for large-scale studies and should be used very cautiously for geographic areas smaller than those described in this paper. The companion map of standard deviation for the age map should be considered for evaluating uncertainty in application of the age map for studying regional carbon, water and nutrient cycles. For the areas with high uncertainty in age estimates such as British Columbia and US west coasts (Fig. 1b) where a greater spatial heterogeneity of forest age cohorts occurs on the landscape, it is particularly critical to choose a proper scale for using the product and perhaps necessary for collecting local data for validation.

We have shown that age is a convenient indicator of forest development status after disturbance, can be easily related to ability of forests to sequester and store carbon, and can support improvements in analysis and modeling techniques. However, age is not the only factor affecting carbon stocks and rate of $\mathrm{C}$ uptake. Climate, atmospheric $\mathrm{CO}_{2}$, air pollution, $\mathrm{N}$ deposition, fertilization, and other factors may be significant (Canadell et al., 2007a; Pan et al., 2009). The data from forest inventories that underlie the carbon stock and NEP curves used in this analysis reflects the aggregate effect of these factors over the region of interest. Therefore, results may be accurate even if the effects of all of the contributing factors are not individually estimated. Finally, forest age maps may be used in conjunction with remote sensing data for driving predictive models of forest dynamics. Although signals from optical remote sensors tend to saturate at the time of tree crown closure, lidar and radar sensors can extend the data to older age classes and higher biomass densities. Models driven by remote sensing, such as CASA (Potter et al., 1993), may benefit from good characterization of forest age in terms of improving the accuracy of gridded estimated of productivity and carbon stocks.

Acknowledgements. Yude Pan and Richard Birdsey acknowledge support from NASA grants (NNH09AM30I and NNH08AH971) and the Forest Service Global Change Research Program. Jing Chen acknowledges support from the Canadian Carbon Program funded by the Canadian Foundation of Climate and Atmospheric Sciences, as well as funding support from US Department of Agriculture and Natural Science and Engineering Council of Canada. We are thankful to John Hom for his useful methodological advice. We owe great thanks to three anonymous reviewers and the editor for their critical and constructive comments, which have substantially improved this manuscript.

Edited by: M. Bahn

\section{References}

Amiro, B. D. and Chen, J. M.: Forest-fire-scar dating using SPOTVEGETATION for Canadian ecoregions, Can. J. Forest Res., 33, 1116-1125, 2003.

Amiro, B. D., Todd, J. B., Wotton, B. M., Logan, K. A., Flannigan, M. D., Stocks, B. J., Mason, J. A., Martell, D. L., and Hirsch, K. G.: Direct carbon emissions from Canadian forest fires, 19591999. Can. J. For. Res. 31, 512-525, 2001.

Barford, C. C., Wofsy, S. C., Goulden, M. L., Munger, J. W., Pyle, E. H., Urbanski, S. P., Hutyra, L., Saleska, S. R., Fitzjarrald, D., and Moore, K.: Factors controlling long- and short-term sequestration of atmospheric $\mathrm{CO}_{2}$ in a mid-latitude forest, Science, 294 , 1688-1691, 2001. 
BC Ministry of Forests: Annual Report of the Ministry of Forests 2002/03, http://www.for.gov.bc.ca/mof/annualreports.htm, 2003.

Bechtold, W. A. and Patterson, P. L. (Eds.): The enhanced Forest Inventory and Analysis program-national sampling design and estimation procedures, Gen. Tech. Rep., SRS-80, Asheville, NC, US Department of Agriculture, Forest Service, Southern Research Station, p. 85, 2005.

Birdsey, R. A., Jenkins, J. C., Johnston, M., Huber-Sannwald, E., Amero, B., de Jong, B., Barra, J. D. E., French, N., Garcia-Oliva, F., Harmon, M., Heath, L. S., Jaramillo, V. J., Johnsen, K., Law, B. E., Marín-Spiotta, E., Masera, O., Neilson, R., Pan, Y., and Pregitzer, K. S.: North American Forests, in: The First State of the Carbon Cycle Report (SOCCR): The North American Carbon Budget and Implications for the Global Carbon Cycle. A Report by the US Climate Change Science Program and the Subcommittee on Global Change Research, edited by: King, A. W., Dilling, L., Zimmerman, G. P., Fairman, D. M., Houghton, R. A., Marland, G., Rose, A. Z., and Wilbanks, T. J.: National Oceanic and Atmospheric Administration, National Climatic Data Center, Asheville, NC, USA, 117-126, 2007.

Birdsey, R. A. and Heath, L. S.: Carbon changes in US forests, in: Productivity of America's Forests and Climate Change, edited by: Joyce, L. A., Gen. Tech. Rep. RM-271, Fort Collins, CO, US Department of Agriculture, Forest Service, Rocky Mtn. Forest and Range Exp. Station, 56-70, 1995.

Birdsey, R. A. and Lewis, G. M.: Current and historical trends in use, management, and disturbance of US forestlands, in: The potential of US forest soils to sequester carbon and mitigate the greenhouse effect, edited by: Kimble, J. M., Linda, H. S., and Birdsey, R. A., New York, CRC Press LLC, 15-33, 2003.

Birdsey, R. A. and Schreuder, H. T.: An overview of forest inventory and analysis estimation procedures in the Eastern United States - with an emphasis on the components of change, Gen. Tech Rep. RM-214, Fort Collins, CO, US Department of Agriculture, Forest Service, Rocky Mountain Forest and Range Experiment Station, p. 11, 1992.

Birdsey, R., Pregitzer, K., and Lucier, A.: Forest carbon management in the United States 1600-2100, J. Environ. Qual., 35, 1461-1469, 2006.

Bolsinger, C. L. and Waddell, K. L.: Area of old-growth forests in California, Oregon, and Washington, Resour. Bull. PNW-RB197, Portland, OR, US Department of Agriculture, Forest Service, Pacific Northwest Research Station, p. 26, 1993.

Bradford, J. B., Birdsey, R. A., Joyce L. A., and Ryan, M. G.: Tree age, disturbance history, and carbon stocks and fluxes in subalpine Rocky Mountain forests, Glob. Change Biol., 14(12), 2882-2897, 2008.

Canadell, J. G., Pataki, D., Gifford, R., Houghton, R. A., Lou, Y., Raupach, M. R., Smith, P., and Steffen, W.: Saturation of the terrestrial carbon sink, in: Ecosystems in a Changing World, edited by: Canadell, J. G., Pataki, D., and Pitelka, L., The IGBP Series, Springer-Verlag, Berlin Heidelberg, 59-78, 2007a.

Canadell, J. G., Le Quéré, C., Raupach, M. R., Field, C. B., Buitehuis, E. T., Ciais, P., Conway, T. J., Houghton, R. A., and Marland, G.: Contributions to accelerating atmospheric $\mathrm{CO}_{2}$ growth from economic activity, carbon intensity, and efficiency of natural sinks, PNAS, Proc. Nat. Aca. Sci., 104, 18866-18870, 2007b.

Chen, J. M. and Cihlar, J.: A hotspot function in a simple bidirectional reflectance model for satellite applications, J. Geophys.
Res., 102, 25907-25913, 1997.

Chen, J. M., Ju, W., Cihlar, J., Price, D., Liu, J., Chen, W., Pan, J., Black, T. A., and Barr, A.: Spatial distribution of carbon sources and sinks in Canada's forests based on remote sensing, Tellus B, 55(2), 622-642, 2003.

Deng, F., Chen, J. M., Yuen, C.-W., Ishizawa, M., Mo, G., Higuchi, K., Chan, D., Chen, B., and Maksyutov, S.: Global monthly $\mathrm{CO}_{2}$ flux inversion with focus over North America, Tellus, 59B, 179190, 2007.

Deng, F., Chen, J. M., Pan, Y., Peter W., Birdsey, R., McCullough, K., and Xiao, J.: Using forest stand-age to constrain an inverse North American carbon flux estimate, Global Biogeochem. Cy., submitted, 2011.

Donnegan, J. A., Veblen, T. T., and Sibold, J. S.: Climatic and human influences on fire history in Pike National Forest, Central Colorado, Can. J. For. Res., 31, 1526-1539, 2001.

Fedkiw, J.: The evolving use and management of the nation's forests, grasslands, croplands, and related resources, USDA Forest Service, Gen. Tech. Rep. RM-175, Ft. Collins, CO, p. 66 , 1989.

Food and Agriculture Organization (FAO): Global forest Resources Assessment, Rome, Italy, p. 320, 2005.

Gallant, A. L., Hansen, A. J., Councilman, J. S., Monte, D. K., and Betz, D. W.: Vegetation dynamics under fire exclusion and logging in a Rocky Mountain watershed, 1856-1996, Ecol. Appl., 13(2), 385-403, 2003.

Greeley, W. B.: Timber depletion, lumber prices, lumber exports, and concentration of timber ownership, US Department of Agriculture, Forest Service, Report on Senate Resolution, 311, p. 39 , 1920.

He, L., Chen, J. M., Zhang, S, Gomez, G., Pan, Y., McCullough, K., and Birdsey, R.: Normalized Algorithm for Mapping and Dating Forest Disturbances and Regrowth for the United States, Journal of Applied Earth Obsevation and Geoinformation, in press, 2011.

Hollinger, D. Y., Aber, J., Dail, B., Davidson, S. M., Goltz, H., and Hughes, H.: Spatial and temporal variability in forestatmosphere $\mathrm{CO}_{2}$ exchange, Glob. Change Biol., 10, 1689-1706, 2004.

Keeling, E. G., Sala, A., and DeLuca, T. H.: Effects of fire exclusion on forest structure and composition in unlogged ponderosa pine/Douglas-fir forests, Forest Ecol. Manag., 237, 418428, 2006.

Kurz, W. A. and Apps, M. J.: An analysis of future carbon budgets of Canadian boreal forests, Water Air Soil Poll., 82, 321-331, 1995.

Kurz, W. A. and Apps, M. J.: A 70-year retrospective analysis of carbon fluxes in the Canadian forest sector, Ecol. Appl., 9, 526547, 1999.

Kurz, W. A., Stinson, G., Rampley, G. J., Dymond, C. C., Neilson, E. T.: Risk of natural disturbances makes future contribution of canada's forests to the global carbon cycle highly uncertain, Proc. Nat. Aca. Sci., 105(5), 1551-1555, 2008a.

Kurz, W. A., Dymond, C. C., Stinson, G., Rampley, G. J., Neilson, E. T., Carroll, A. L., Ebata, T., and Safranyik, L.: Mountain pine beetle and forest carbon feedback to climate change, Nature, 452(24), 987-990, 2008b.

Larson, R. W.: South Carolina's timber, Forest Survey Release 55 , USDA Forest Service, Southeastern Forest Experiment Station, Asheville, NC, 1960. 
Law, B. E., Sun, O. J., Campbell, J., Vantuyl, S., and Thornton, P. E.: Changes in carbon storage and fluxes in a chronosequence of ponderosa pine, Glob. Change Biol., 9, 510-524, 2003.

Le Quéré, C., Raupach, M. R., Canadell, J. G., Marland, G., Bopp, L., Ciais, P., Conway, T. J., Doney, S. C., Feely, R. A., Foster, P., Friedlingstein, P., Gurney, K., Houghton, R. A., House, J. I., Huntingford, C., Levy, P. E., Lomas, M. R., Majkut, J., Metzl, N., Ometto, J. P., Peters, G. P., Prentice, I. C., Randerson, J. T., Running, S. W., Sarmiento, J. L., Schuster, U., Sitch, S., Takahashi, T., Viovy, N., van der Werf, G. R., and Woodward, F. I.: Trends in the sources and sinks of carbon dioxide, Nat. Geosci., 2, 831-836, 2009.

Lowe, J. J., Power, K., and Gray, S. L.: Canada's forest inventory 1991: the 1994 version-technical supplement, Canada Forest Service, Information Report BC-X-362E, 1996.

Luyssaert, S., Schulze, E.-D., Börner, A., Knohl,A., Hessenmöller, D., Law, B. E., Ciais, P., and Grace, J.: Old-growth forests as global carbon sinks, Nature, 455, 213-215, 2008.

MacCleery, D. W.: American forests - a history of resiliency and recovery, FS-540, USDA Forest Service, Washington, DC, p. 58, 1992.

Masek, J. G., Huang, C., Wolfe, R., Cohen, W., Hall, F., Kutler, J., and Nelson, P.: North American forest disturbance mapped from a decadal Landsat record, Remote Sens. Environ., 112, 29142926, 2008.

Nabuurs, G. J., Masera, O., Andrasko, K., Benitez-Ponce, P., Boer, R., Dutschke, M., Elsiddig, E., Ford-Robertson, J., Frumhoff, P., Karjalainen, T., Krankina, O., Kurz, W. A., Matsumoto, M., Oyhantcabal, W., Ravindranath, N. H., Sanz Sanchez, M. J., and Zhang, X.: Forestry, in: Climate Change 2007: Mitigation, Contribution of Working Group III to the Fourth Assessment Report of the Intergovernmental Panel on Climate Change, edited by: Metz, B., Davidson, O. R., Bosch, P. R., Dave, R., and Meyer, L. A., Cambridge University Press, Cambridge, United Kingdom and New York, NY, USA, 2007.

Ollinger, S. V., Aber, J. D., Reich, P. B., and Freuder, R. J.: Interactive effects of nitrogen deposition, tropospheric ozone, elevated $\mathrm{CO}_{2}$ land use history on the carbon dynamics of northern hardwood forests, Glob. Change Biol., 8, 545-562, 2002.

Pan, Y., McGuire, A. D., Melillo, J. M., Kicklighter, D. W., Sitch, S., and Prentice, I. C.: A biogeochemistry-based successional model and its application along a moisture gradient in the continental United States, J. Veg. Sci., 13, 369-380, 2002.

Pan, Y., Birdsey, R., Hom, J., McCullough, K., and Clark, K.: Improved estimates of net primary productivity from MODIS satellite data at regional and local scales, Ecol. Appl., 16(1), 125-132, 2006.

Pan, Y., Birdsey, R., Hom, J., and McCullough, K.: Separating Effects of Changes in Atmospheric Composition, Climate and Land-use on Carbon Sequestration of US Mid-Atlantic Temperate Forests, Forest Ecol. Manag., 259, 151-164, 2009.

Pan, Y., Birdsey, R., McCullough, K., Chen, J. M., and Wayson, C.: The benchmark for carbon models: Net ecosystem productivity of US forests estimated from forest inventory data, AIMES Open Science Conference, Earth System Science 2010: Global Change, Climate and People, Edinburgh, Abstract Book, p. 50, 2010.

Penner, M., Power, K., Muhairwe, C., Tellier, R., and Wang, Y.: Canada's forest biomass resources: deriving estimates from
Canada's forest inventory, Information Report BC-X-370, Pacific Forestry Centre, Canadian Forest Service, Natural Resources Canada, 1997.

Peters, W., Jacobson, A. R., Sweeney, C., Andrews, A. E., Conway, T. J., Masarie, K., Miller, J. B., Bruhwiler, L. M. P., Pétron, G., Hirsch, A. I., Worthy, D. E. J., van der Werf, G. R., Randerson, J. T., Wennberg, P.O., Krol, M. C., and Tans, P. P.: An atmospheric perspective on North American carbon dioxide exchange: CarbonTracker, Proc. Nat. Aca. Sci., 104(48), 18925-18930, 2007.

Post, W. M. and Kwon, K. C.: Soil carbon sequestration and landuse change: processes and potential, Glob. Change Biol., 6, 317327, 2000.

Potter, C. S., Ranserson, J. T., Field, C. B., Matson, P. A., Vitousek, P. M., Mooney, H. A., and Jlooster, S. A.: Terrestrial ecosystem production: a process model based on global satellite and surface data, Global Biogeochem. Cy., 7, 811-841, 1993.

Pregitzer, K. and Euskirchen, E.: Carbon cycling and storage in world forests: biome patterns related to forest age, Glob. Change Biol., 10, 2052-2077, 2004.

Ruefenacht, B., Finco, M. V., Nelson, M. D., Czaplewski, R., Helmer, E. H., Blackard, J. A., Holden, G. R., Lister, A. J., Salajanu, D., Weyermann, D., and Winterberger, K.: Conterminous US and Alaska Forest Type Mapping Using Forest Inventory and Analysis Data, Photogramm. Eng. Rem. S., 74(11), 1379-1388, 2008.

Smith, J. E., Heath, L. S., Skog, K. E., and Birdsey, R. A.: Methods for Calculation Forest Ecosystem and Harvested Carbon with Standard Estimates for Forest Types of the United States, Gen. Tech. Rep. NE-343, Newtown Square, PA, USDA, Forest Service, Northeastern Research Station, 216, 2006.

Sisk, T. D. (Ed.): Perspectives on the land use history of North America: a context for understanding our changing environment, US Geological Survey, Biological Resources Division, Biological Science Report USGS/BRD/BSR-1998-0003, p. 104, 1998.

Sitch, S., Huntingford, C., Gedney, N., Levy, P. E., Lomass, M., Piao, S. L., Betts, R., Ciais, P., Cox, P., Friedlingstein, P., Jones, C. D., Preentice, I. C., and Woodward, F. I.: Evaluation of the terrestrial carbon cycle, future plant geography and climate-carbon cycle feedbacks using five Dynamic Global Vegetation Models (DGVMs), Glob. Change Biol., 14, 2015-2039, 2008.

Smoyer-Tomic, K. E., Justine, Klaver, J. D. A., Soskolne, C. L., and Spady, D. W.: Health Consequences of Drought on the Canadian Prairies, EcoHealth, 1 (Suppl. 2), 144-154, 2004.

Stephens, B. B., Gurney, K. R., Tans, P. P., Sweeney, C., Peters, W., Bruhwiler, L., Ciais, P., Ramonet, M., Bousquet, P., Nakazawa, T., Aoki, S., Machida, T., Inoue, G., Vinnichenko, N., Lloyd, J., Jordan, A., Heimann, M., Shibistova, O., Langenfelds, R. L., Steele, L. P., Francey, R. J., and Denning, A. S.: Weak Northern and Strong Tropical Land Carbon Uptake from Vertical Profiles of Atmospheric $\mathrm{CO}_{2}$, Science, 316, 1732-1735, 2007.

Stocks, B. J., Mason, J. A., Todd, J. B., Bosch, E. M., Wotton, B. M., Amiro, B. D., Flannigan, M. D., Hirsch, K. G., Logan, K. A., Martell, D. L., and Skinner, W. R.: Large forest fires in Canada, 1959-1997, J. Geophys. Res., 108(D1), 8149, doi:10.1029/2001JD000484, 2003.

US Forest Service: Land areas of the National Forest System, FS383, Washington, DC, p. 154, 2005.

US Department of Agriculture: US Agriculture and Forestry Greenhouse Gas Inventory: 1990-2005, Global Change Pro- 
gram Office, Office of the Chief Economist, US Department of Agriculture, Technical Bulletin No. 1921, 161 pp. (available at: http://www.usda.gov/oce/global_change/ AFGGInventory1990_2005.htm), 2008.

Weber, M. G. and Flannigan, M. D.: Canadian boreal forest ecosystem structure and function in changing climate: Impact on fire regimes, Environ. Rev., 5, 145-166, 1997.
Williams, D. W. and Birdsey, R. A.: Historical patterns of spruce budworm defoliation and bark beetle outbreaks in North American conifer forests: an atlas and description of digital maps, Gen. Tech. Rep. NE-308, Newtown Square, PA, US Department of Agriculture, Forest Service, Northeastern Research Station, 133, 2003.

Zhou, G., Liu, S., Li, Z., Zhang, D., Tang, X., Zhou, C., Yan, J, and Mo, J.: Old-growth forests can accumulate carbon in soils, Science, 314, 1417, doi:10.1126/science.1130168, 2006. 